\title{
МОРФОЛОГІЧНІ ПРОЯВИ АПОПТОТИЧНОЇ ЗАГИБЕЛІ КЛІТИН ЛІМФОВУЗЛІВ І ТИМУСА МИШЕЙ ПРИ ЗАСТОСУВАННІ КОНКАНАВАЛІНУ А
}

\author{
ОТ.М. Бризгіна, В.С. Сухіна, Н.Г. Грушка, Н.В. Макогон \\ Інститут фізіології ім. О.О. Богомольця НАН України, Київ
}

РЕЗЮМЕ. Досліджували рівень спонтанної й індукованої дексаметазоном і етопозидом апоптотичної загибелі, а також морфологічні прояви апоптозу в клітинах лімфовузлів і тимуса мишей в умовах ушкодження печінки введенням Т-клітинного мітогена конканаваліну А (КонА, 15 і 30 мг/кг). Метод прижиттєвого подвійного забарвлення клітин тимуса і лімфовузлів (культивованих протягом 18 годин) флуоресцентними барвниками Хехст 33342 і пропідіум йодид дозволив диференціювати апоптоз на ранніх (конденсація хроматину) і пізніх (пікноз і фрагментація ядер) його стадіях, а також виявити клітини з ознаками вторинного (постапоптотичного) некрозу. Встановлено, що за умов введення КонА дозозалежно посилювався індукований апоптоз клітин лімфовузлів і збільшувався відсоток клітин на пізніх стадіях апоптозу з ушкодженням плазматичної мембрани. Спостерігалося підвищення відсотка клітин лімфовузлів і тимуса з морфологічними ознаками постапоптотичного некрозу, а також загальної кількості клітин з втратою цілості плазматичної мембрани. Значне посилення постапоптотичного некрозу може бути одним з механізмів виникнення і посилення запальних процесів в печінці.

КЛЮЧОВІ СЛОВА: конканавалін А, імунний гепатит, тимоцити, клітини лімфовузлів, апоптоз, вторинний некроз, миші.

Вступ. Мітоген КонА викликає ушкодження печінки, що є класичною моделлю імунного гепатиту, опосередкованого активацією Т-лімфоцитів $[3,9,11]$. Вони інфільтрують печінку і викликають апоптоз її клітин, що є одним 3 механізмів ураження печінки. В активованих Тлімфоцитах також розвивається апоптоз. Разом з тим біохімічні та морфологічні дослідження вказують на некротичну загибель клітин і запальні процеси в печінці, механізми виникнення і розвитку яких вивчені недостатньо. Відомо, що апоптотичні клітини швидко поглинаються як спеціалізованими фагоцитами, так і сусідніми клітинами і не викликають запалення. Однак за умов недостатньої енергозабезпеченості апоптозу, послаблення фагоцитозу за наявності інших пронекротичних факторів може відбуватись ушкодження плазматичної мембрани на різних стадіях апоптозу (вторинний постапоптотичний некроз), клітинний вміст виділяється назовні, що $€$ сильним стимулом розвитку запалення і реакції імунної системи $[1,4,7]$. Ми вважаємо, що важливими для оцінки ступеня розвитку запальних процесів в печінці і прогнозу їх подальших змін можуть бути параметри, які характеризують апоптоз, різні його стадії та вторинний некроз лімфоцитів, оскільки ці клітини інфільтрують печінку при їі КонА-індукованому ушкодженні $[8,9,11]$ і $€$ швидкореагуючою, чутливою до змін гомеостазу популяцією клітин, стан якої віддзеркалює рівень активації механізмів виживання/загибелі клітин організму [1, 2].

Мета роботи - охарактеризувати спонтанний та індукований апоптоз клітин лімфовузлів і тимуса в культурі за умов введення мишам мітогена КонА.
Матеріал і методи дослідження. Дослідження проводилися на статевозрілих самцях щурів лінії СВА. При роботі дотримувались Міжнародних принципів Європейської конвенції про захист хребетних тварин.

КонA ("Sigma") вводили в хвостову вену в дозах 15 і 30 мг/кг. Через 20 годин клітини пахових лімфовузлів і тимуса виділяли за загальноприйнятою методикою. Клітини (1х106 в 200 мкл середовища) культивували протягом 18 год при $37^{\circ} \mathrm{C}$ в середовищі RPMI 1640 з додаванням 15 ммоль/л HEPES ("Sigma"), 10 \% ембріональної телячої сироватки та антибіотиків. В культури вносили дексаметазону фосфат (KRKA,Slovenia, 25 мкмоль/л) або етопозид ("Ebewe", Austria, 80 мкмоль/л).

Метод прижиттєвого подвійного забарвлення флуоресцентними барвниками нуклеїнових кислот Хехст 33342 ("Sigma") та пропідіум йодид ("Sigma") дає можливість визначити кількість живих, апоптотичних і некротичних клітин. Пропідіум йодид проникає тільки в клітини з ушкодженими мембранами (тобто некротичні) або клітини з ушкодженням плазматичної мембрани на різних стадіях розвитку апоптозу (постапоптотичний некроз), а Хехст 33342 проникає і через неушкоджені мембрани. Зв'язані з хроматином барвники дають змогу оцінити морфологічні риси ядерного матеріалу, притаманні апоптозу: периферичне розташування хроматину, його конденсацію, пікноз і фрагментацію ядер. Забарвлення проводили барвниками в кінцевій концентрації 10 мкмоль/л на протягом 25 хвилин [10]. Використовували відеосистему передачі зображення з люмінесцентного мікроскопа Люмам I-1 (водно-імерсійний об'єктив х 85) на ком- 
Огляди літератури, оригінальні дослідження, погляд на проблему, короткі повідомлення, замітки з практики

п'ютер. Визначали від живих, апоптотичних та некротичних клітин, а також відсоток клітин 3 різними морфологічними формами апоптозу при підрахунку не менше як 200 клітин. Статистичну обробку проводили методом Стьюдента.

Результати й обговорення. Встановлено, що при введенні мишам КонА зменшувався відсоток інтактних клітин і посилювався апоптоз культивованих клітин лімфовузлів і тимуса (табл. 1).
Зміни були більш виражені в клітинах лімфовузлів, культивованих в присутності індукторів апоптозу і мали дозозалежний характер.

Для характеристики морфологічних проявів клітинної загибелі вирізняли клітини з такими формами апоптозу: тип 1 - ядра з конденсованим хроматином і незначним зменшенням розмірів, плазматична мембрана неушкоджена; тип 2 - ядра, як в клітинах типу 1, плазматична

Таблиця 1. Відсоток живих та апоптотичних клітин лімфовузлів і тимуса мишей за умов дії Кон А в дозах 15 і 30 мг/кг (M $\pm \mathrm{m})$

\begin{tabular}{|l|c|c|c|c|c|}
\hline \multirow{2}{*}{ І } & \multirow{2}{*}{ Індуктор } & \multicolumn{2}{|c|}{ Клітини лімфовузлів } & \multicolumn{2}{c|}{ Клітини тимуса } \\
\cline { 3 - 6 } & & Живі кл & Апопто3 & Живі кл & Апопто3 \\
\hline Контроль & Без індуктора & $44,6 \pm 5,9$ & $52,6 \pm 5,4$ & $46,2 \pm 6,0$ & $50,2 \pm 6,9$ \\
\hline КонА 15 мг/кг & Без індуктора & $37.0 \pm 3.7$ & $59.6 \pm 3.2$ & $27.4 \pm 4.7^{*}$ & $69.8 \pm 5.2^{*}$ \\
\hline КонА 30 мг/кг & Без індуктора & $38.3 \pm 5.8$ & $58.5 \pm 5.1$ & $38.3 \pm 8.8$ & $57.4 \pm 9.7$ \\
\hline Контроль & Дексаметазон & $20.0 \pm 1.5$ & $75.6 \pm 1.3$ & $27.2 \pm 7.3$ & $69.7 \pm 7.9$ \\
\hline КонА 15 мг/кг & Дексамета3он & $12.9 \pm 1.9^{*}$ & $81.9 \pm 1.2^{*}$ & $11.5 \pm 1.8$ & $85.8 \pm 2.3$ \\
\hline КонА 30 мг/кг & Дексаметазон & $9.8 \pm 1.7^{*}$ & $87.2 \pm 2.8^{*}$ & $24.7 \pm 8.2$ & $70.6 \pm 8.7$ \\
\hline Контроль & Етопозид & $15.8 \pm 1.5$ & $79.7 \pm 1.6$ & $21.5 \pm 5.5$ & $72.5 \pm 7.0$ \\
\hline КонА 15 мг/кг & Етопозид & $11.3 \pm 3.4$ & $81.6 \pm 3.3$ & $10.0 \pm 2.3$ & $86.8 \pm 3.2$ \\
\hline КонА 30 мг/кг & Етопозид & $8.4 \pm 2.2^{*}$ & $89.0 \pm 2.6^{*}$ & $11.6 \pm 2.9$ & $81.0 \pm 4.0$ \\
\hline
\end{tabular}

Примітка: * - P<0,05 відносно контролю.

мембрана ушкоджена; тип 3 - пікнотичні або фрагментовані ядра з сильноконденсованим хроматином, плазматична мембрана неушкоджена; тип 4 - ядра, як в клітинах типу 3, плазматична мембрана ушкоджена. Клітини типу 1 і 2 знаходяться на ранніх стадіях розвитку апоптозу, типу 3 і 4 - на пізніх стадіях, що передують розпаду клітини на апоптотичні тільця та її фагоцитозу. В дослідженні вираховували сумарну кількість вториннонекротичних клітин (типу 2 і 4), які мали ушкоджені плазматичні мембрани (ядра, забарвлені йодидом пропідіума) і виражені ядерні ознаки апоптозу. Визначали також сумарний відсоток клітин з порушеною цілістю плазматичної мембрани (тобто, первинно- і вториннонекротичних клітин). Встановлено, що в клітинах лімфовузлів і тимуса мишей відбувалися суттєві зміни морфологічних проявів апоптозу (табл. 2). Спостерігалось значне підвищення (за умов індукції апоптозу) кількості клітин лімфовузлів з постапоптотичним некрозом, а також сумарної кількості первинно- і вториннонекротичних клітин. Зміни цих показників носили дозозалежний характер, що робить їх перспективними для оцінки співвідношення проапоптотичних/пронекротичних факторів в організмі. За умов індукції апоптозу зменшувався також відсоток клітин на пізніх стадіях розвитку апоптозу з неушкодженою плазматичною мембраною (тип 3) і підвищувався відсоток таких клітин з ушкодженою мембраною (тип 4), однак загалом в даній моделі ушкодження печінки показники різних стадій розвитку апоптозу (типи 1-4) виявилися досить варіабельними. Аналіз даних, отриманих на клітинах тимуса, виявив ту ж основну закономірність, що і для клітин лімфовузлів: збільшення апоптозу, вторинного постапоптотичного некрозу і загальної кількості некротичних клітин (табл. 1,2). Однак для клітин тимуса були виявлені більші зміни апоптозу за умов дії меншої дози КонА. Причини такого ефекту ще мають бути досліджені, однак можна припустити, що за умов сильної активації Т-клітин великою дозою мітогена КонА відбувається зрив гомеостатичного механізму регуляції проліферації/апоптозу Т-клітин. Зіставлення дії двох індукторів апоптозу - дексаметазону і етопозиду - показало, що вони викликають однонаправлені зміни в апоптозі клітин лімфовузлів і тимуca.

Застосований підхід з визначенням різних морфологічних форм апоптозу лімфоцитів, зокрема їх постапоптотичного некрозу, дає можливість обґрунтувати деякі механізми розвитку КонА-індукованого ушкодження печінки. Відомо, що печінка є місцем посиленої міграції, апоптозу і елімінації активованих Т-клітин, особливо СД 8+ Т-клітин як в нормі, так і за умов її імунного ушкодження [5, 6, 8, 9]. Ми показали, що КонА викликає значне підвищення апоптозу лімфо- 
Таблиця 2. Клітини лімфовузлів і тимуса мишей з різними морфологічними ознаками апоптозу (відсоток від загальної кількості) за умов дії КонА в дозах 15 і 30 мг/кг (спонтанний апоптоз - Сп, або індукований дексаметазоном -Декс чи етопозидом -Ет) ( $\mathrm{M} \pm \mathrm{m})$

\begin{tabular}{|c|c|c|c|c|c|c|c|}
\hline & $\begin{array}{c}\text { Індук } \\
\text { тор }\end{array}$ & Тип 1 & Тип 2 & Тип 3 & Тип 4 & $\begin{array}{c}\text { Вторинний } \\
\text { некроз }\end{array}$ & $\begin{array}{c}\text { Первинний і } \\
\text { вто-ринний } \\
\text { некроз }\end{array}$ \\
\hline \multicolumn{8}{|c|}{ Клітини лімфовузлів } \\
\hline Контроль & \multirow{3}{*}{ Сп } & $4,6 \pm 2,6$ & $9,1 \pm 1,1$ & $14,8 \pm 1,4$ & $24,1 \pm 5,9$ & $33.2 \pm 6.2$ & $36.0 \pm 6.9$ \\
\hline КонА 15 & & $9,4 \pm 3,1$ & $8,9 \pm 2,0$ & $11,8 \pm 2,0$ & $29,6 \pm 5,2$ & $38.5 \pm 3.5$ & $41.9 \pm 4.2$ \\
\hline КонА 30 & & $7,9 \pm 2,9$ & $10,5 \pm 4,0$ & $13,6 \pm 2,4$ & $26,5 \pm 6,4$ & $36.9 \pm 5.2$ & $40.2 \pm 5.8$ \\
\hline Контроль & \multirow{3}{*}{ Декс } & $8,3 \pm 4,0$ & $11,5 \pm 4,0$ & $27,9 \pm 2,6$ & $27,9 \pm 4,8$ & $39.4 \pm 3.3$ & $43.8 \pm 4.1$ \\
\hline КонА 15 & & $5,8 \pm 2,0$ & $10,4 \pm 2,7$ & $17,3 \pm 3,0 *$ & $48,5 \pm 3,5 * *$ & $58.8 \pm 1.7 * * *$ & $64.1 \pm 2.0^{* *}$ \\
\hline КонА 30 & & $7,8 \pm 3,0$ & $19,1 \pm 7,3$ & $19,8 \pm 3,9$ & $40,4 \pm 7,9$ & $59.6 \pm 4.3^{* *}$ & $62.6 \pm 4.2^{* *}$ \\
\hline Контроль & \multirow{3}{*}{$\mathrm{ET}$} & $5,0 \pm 2,3$ & $11,2 \pm 3,5$ & $30,5 \pm 3,7$ & $33,0 \pm 2,5$ & $44.3 \pm 2.1$ & $48.7 \pm 1.8$ \\
\hline КонА 15 & & $7,4 \pm 3,8$ & $11,1 \pm 5,1$ & $22,5 \pm 3,9$ & $36,6 \pm 4,4$ & $47.7 \pm 6.5$ & $54.8 \pm 6.2$ \\
\hline КонА 30 & & $6,6 \pm 2,2$ & $23,8 \pm 9,4$ & $17,7 \pm 4,3^{*}$ & $40,8 \pm 5,8$ & $64.7 \pm 5.7 * *$ & $67.3 \pm 5.2^{* *}$ \\
\hline \multicolumn{8}{|c|}{ Клітини тимуса } \\
\hline Контроль & \multirow{3}{*}{ Сп } & $8,7 \pm 1,5$ & $6,8 \pm 0,4$ & $22,8 \pm 5,0$ & $11,9 \pm 3,2$ & $18.6 \pm 3.1$ & $22.2 \pm 2.3$ \\
\hline КонА 15 & & $11,6 \pm 3,4$ & $14,8 \pm 3,6$ & $25,8 \pm 6,7$ & $17,7 \pm 4,8$ & $32.4 \pm 2.2^{* *}$ & $35.2 \pm 2.3^{* *}$ \\
\hline КонА 30 & & $8,1 \pm 2,7$ & $4,2 \pm 1,4$ & $24,1 \pm 6,7$ & $21,0 \pm 6,5$ & $25.1 \pm 5.7$ & $29.5 \pm 4.9$ \\
\hline Контроль & \multirow{3}{*}{ Декс } & $12,8 \pm 2,8$ & $8,3 \pm 1,8$ & $30,7 \pm 7,3$ & $17,8 \pm 1,8$ & $26.1 \pm 1.4$ & $29.2 \pm 1.7$ \\
\hline КонА 15 & & $11,5 \pm 2,7$ & $18,0 \pm 5,1$ & $30,4 \pm 6,8$ & $26,0 \pm 4,0$ & $44.0 \pm 3.6^{* * *}$ & $46.6 \pm 4.1^{* *}$ \\
\hline КонА 30 & & $7,4 \pm 2,7$ & $10,5 \pm 3,0$ & $27,4 \pm 6,3$ & $25,4 \pm 7,3$ & $35.9 \pm 5.8$ & $40.6 \pm 5.7$ \\
\hline Контроль & \multirow{3}{*}{ ET } & $14,3 \pm 2,8$ & $12,2 \pm 1,6$ & $28,3 \pm 5,2$ & $17,7 \pm 2,3$ & $29.9 \pm 2.1$ & $35.8 \pm 2.2$ \\
\hline КонА 15 & & $14,0 \pm 3,8$ & $22,5 \pm 6,3$ & $29,4 \pm 7,3$ & $20,9 \pm 4,8$ & $43.4 \pm 2.8 * *$ & $46.5 \pm 3.3^{*}$ \\
\hline КонА 30 & & $12,3 \pm 3,6$ & $14,9 \pm 3,5$ & $28,3 \pm 4,8$ & $25,6 \pm 5,5$ & $40.4 \pm 3.8^{*}$ & $47.8 \pm 3.0^{* *}$ \\
\hline
\end{tabular}

Примітка: * - P<0,05; ** - $\mathrm{P}<0,01 ;{ }^{* \star *}-\mathrm{P}<0,001$ відносно контролю.

цитів, при цьому збільшується кількість апоптотичних клітин з порушенням цілісності плазматичної мембрани. Це призводить до виходу внутрішньоклітинного вмісту і стимуляції запалення. Відомо також, що фагоцитоз клітин в стадії постапоптотичного некрозу уповільнений $[4,7]$. Сумарна дія цих двох обставин обумовлює те, що збільшення постапоптотичного некрозу лімфоцитів в печінці може бути суттєвим механізмом виникнення і розвитку запалення при імунному ураженні печінки Т-клітинного генезу.

Висновки. 1. Встановлено, що введення мишам Т-клітинного мітогена Кон А стимулює спонтанний та індукований дексаметазоном і

\section{ЛITEPAТУРА}

1.Буеверов А.О., Тихонина Е.В., Москалева Е.Ю. и др. Апоптоз периферических лейкоцитов при хронических вирусных гепатитах // Рос. журн. гастроэнтерол., гепатол., колопроктол. - 2000. - № 6. - С. 30-33.

2.Игрунова К.Н., Моторная М.М., Степачова Т.И. Апоптоз мононуклеарных клеток крови у больных с патологией сердечно-сосудистой системы // Лабораторная диагностика - 2004. - № 1. - С. 16-18.

3. Мартынова Т.В., Алексеева И.Н., Алексюк Л.И. и др. Функциональная активность перитонеальных макрофагов и гибель иммунокомпетентных клеток у етопозидом апоптоз культивованих клітин лімфовузлів і тимуса, а також розвиток вторинного постапоптотичного некрозу.

2. Посилення постапоптотичного некрозу лімфоцитів може бути одним з механізмів розвитку запалення при гепатиті Т-клітинного генезу.

Перспективи подальших досліджень. Ми вважаємо перспективними подальші дослідження параметрів індукованого апоптозу лімфоцитів (особливо відсотка вториннонекротичних клітин) при захворюваннях печінки з метою створення діагностично-прогностичної оцінки розвитку запалення.

мышей // Медицинская иммунология. - 2006. - Т. 8, № 2-3. - С. 156.

4. Проскуряков С.Я., Габай В.Л., Коноплянников А.Г. и др. Иммунология апоптоза и некроза // Биохимия. 2005. - T. 70, № 12. - С. 1593-1605.

5. Bertolino P., Trescol-Biemont M.C., Thomas J. et al. Death by neglect as a deletional mechanism of peripheral tolerance//Int. Immunol. - 1999. - Vol. 11, № 8. - P. 1225-1238.

6. Crispe I.N., Dao T., Klugewitz K. et al. The liver as a site of T-cell apoptosis: graveyard, or killing field? // Immunol Rev. - 2000. - Vol. 174, № 4. - P. 47-62. 
Огляди літератури, оригінальні дослідження, погляд на проблему, короткі повідомлення, замітки з практики

7. Jaeschke H., Lemasters J.J. Apoptosis versus oncotic necrosis in hepatic ischemia/reperfusion injury // Gastroenterology. - 2003. - Vol. 125, № 4. - P. 1246-1257.

8. Park S., Murray D., John B., Crispe I.N. Biology and significance of T-cell apoptosis in the liver // Immunol. Cell Biol. - 2002. - Vol. 80, № 1. - P. 74-83.

9. Peters M.G. Animal models of autoimmune liver disease // Immunol. Cell Biol. - 2002. - Vol. 80, № 1. - P. 113-116.
10. Shimizu S., Eguchi Y., Kamiike W. et al. Involvement of ICE family proteases in apoptosis induced by reoxygenation of hypoxic hepatocytes //Am. J. Physiol. -1996. - Vol. 271, № 34. - P. 949-958.

11. Tiegs G., Hentschell J., Wendel A. A T celldependent experimental liver injury in mice inducible by concanavalin A // J. Clin. Invest. - 1992. - Vol. 90, № 1. P. 196-203.

\title{
MORPHOLOGICAL FEATURES OF APOPTOSIS IN CULTURED THYMIC AND LYMPH NODE CELLS IN CONCANAVALIN A-TREATED MICE

\author{
CT.M. Bryzhina, V.S. Sukhina, N.H. Hrushka, N.V. Makohon \\ Institute of Physiology by O.O. Bohomolets of National Academy of Sciences, Kyiv
}

SUMMARY. The experimental mice model of immune liver failure induced by intravenous injection of T-cellular mitogen concanavalin A (Con A, 15 and $30 \mathrm{mg} / \mathrm{kg}$, for 20h) has been investigated in the present work. The level of apoptosis (spontaneous and dexamethasone or etoposide induced) and the morphological features of apoptosis were studied in cultured for $18 \mathrm{~h}$ thymic and lymph node cells. A double vital staining by fluorescent dyes Xoechst 33342 and propidium iodide allowed to differentiate the early (chromatin condensation) and the late (pycnotic and fragmented nuclei) stages of apoptosis as well as the secondary necrotic cells. ConA treatment was accompanied with the dose-dependent increase in the induced apoptosis of lymph node cells and with the increase in the percentage of cells in the late stage of apoptosis and with plasma membrane disruption. The percentage of thymic and lymph node cells with the features of secondary (postapoptotic) necrosis was enhanced, as well as the common percent of the cells with disrupted plasma membrane. The significant increase in the postapoptotic necrosis might be one of the mechanisms in the development of inflammation in the liver.

KEY WORDS: concanavalin A, immune hepatitis, thymic and lymph node cells, apoptosis, secondary necrosis, mice.

УДК 616.831.38+073.756.8

\section{АНАТОМО-КЛІНІЧНІ АСПЕКТИ ОЦІНКИ ЛІКВОРНИХ ПРОСТОРІВ ГОЛОВНОГО МОЗКУ}

\author{
๑І.П. Вакуленко, Н.В. Танасічук-Гажиєва, О.В. Губенко, Г.В. Губенко \\ Донецький державний медичний університет
}

РЕЗЮМЕ. Проаналізовано стан лікворних просторів головного мозку за даними комп'ютерної томографії у 100 осіб різного віку в нормі. Використовували лінійні, об'ємні та відносні показники. Вимірювання ширини центральних частин бокових шлуночків є об'єктивним показником їх стану. Авторами запропонований об'ємний індекс шлуночкової системи. Він стабільний в усіх вікових групах.

КЛЮЧОВІ СЛОВА: головний мозок, лікворні простори, рентгенівська комп'ютерна томографія.

Вступ. Оцінка стану лікворних просторів головного мозку має велике значення при виборі виду лікування нейрохірургічних хворих (консервативного або оперативного). Швидка динаміка об'ємів лікворних просторів спостерігається при черепно-мозкової травмі (ЧМТ).

Особливе значення має їх об'єктивізація при розвитку у пацієнтів збільшення об'єму головного мозку, обумовленого гіперемією, набряком, набряканням або їх поєднанням. В цих випадках комп'ютерно-томографічною (КТ) ознакою цих явищ є зменшення об'ємів лікворних просторів.
Разом з тим може виникнути порушення циркуляції та резорбції ліквору, яке потребує активного хірургічного втручання [1]. Посттравматичну гідроцефалію необхідно диференціювати 3 процесами заміщення зменшуваного в об'ємі мозку церебральною рідиною - дифузними атрофічними змінами [2]. Для обох видів змін характерне збільшення шлуночкової системи.

Різний стан лікворних просторів пацієнтів до ЧМТ створює труднощі при оцінці впливу травми на лікворообіг. Труднощі діагностики відзначаються у пацієнтів з преморбідними дифузними атрофічними змінами мозку, коли субарахної- 
дальні простори можуть залишатися розширеними. Крім того, тривала посттравматична гідроцефалія приводить до зменшення об'єму паренхіми мозку.

Способи об'єктивізації об'ємів лікворних просторів, за даними КТ-досліджень, є дискусійними. Запропонована оцінка об'ємів за допомогою відносних величин - церебровентрикулярних індексів [3, 4, 5] неефективна через деформацію бокових шлуночків (БШ) у результаті об'ємного впливу осередкових пошкоджень мозку. Крім цього, діапазон цих показників, за даними різних авторів, великий [5]. Дані про об'єми БШ, запропоновані анатомами, не можна порівнювати з даними КТ, тому що остання відображує кількість ліквору в порожнинах на момент дослідження, а не об'єм БШ.

Мета дослідження - оцінити найоб'єктивніший і доступний спосіб визначення об'ємів лікворних просторів у клінічних умовах за даними КT.

Матеріал і методи дослідження. Проведено аналіз КТ-досліджень головного мозку 100 пацієнтів, у яких при неврологічному та інструментальному дослідженні патології головного мозку не виявили (КТ проводили для виключення ЛОР-патології).

Під наглядом перебували пацієнти віком від 18 до 85 років. Середній вік склав $(45,1 \pm 3,76)$ року.

Пацієнтів розподілили за віком відповідно до рекомендацій ВООЗ. У кожної групі було по 20 пацієнтів. Чоловіків було 38, жінок - 62.

Використовували лінійні, об'ємні та відносні показники лікворних просторів.

Вимірювали відстань між верхівками передніх рогів, мінімальний розмір між латеральними стінками передніх рогів, найбільший поперечний розмір заднього рога, відстань між судинними сплетеннями задніх рогів, ширину центральних частин БШ, максимальні відстані між внутрішніми пластинками кісток черепа на рівні тіл і передніх рогів БШ.

Для оцінки розмірів третього шлуночка використовували його ширину. При аналізі субарахноїдального простору особливу увагу приділяли стану цистерн основи мозку. Оцінювали їх лінійні розміри.

Планіметричним методом [6] визначали об'єм цистерни бічної ямки великого мозку, оскільки лінійними показниками важко охарактеризувати ії складну форму. Також його використовували для обчислення об'єму ліквору в БШ, що дозволяло врахувати і ту частину рідини, яка знаходилась у нижніх рогах.

Цим же методом обчислювали абсолютний та відносний об'єм головного мозку.
За допомогою цифрового варіанта гістографії КТ-сканограм одержували значення об'ємів лікворних просторів і БШ [7].

Розраховували відносні показники - церебровентрикулярні індекси: передніх рогів, центральних частин БШ, задніх рогів, Хакмана-Цаля, Ширеманна, відношення відстані між хоріоїдальними сплетеннями і максимальним розміром між латеральними стінами передніх рогів.

Для визначення переваги кількості ліквору в шлуночковій системі і субарахноїдальних просторах розраховували об'ємний індекс БШ [8]. Індекс визначали за формулою:

УБШ = об'єм БШ : об'єм лікворних просторів 100 \%, де УБШ - об'ємний індекс БШ.

Лінійні і відносні показники співвідносили зі значеннями об'ємів БШ і лікворних просторів.

Результати й обговорення. Отримані показники шлуночкової системи і субарахноїдальних лікворних просторів, залежно від віку, наведено в таблицях 1 і 2.

Розміри БШ збільшувалися з віком, достовірно відрізнялися тільки у молодих пацієнтів. При цьому об'ємний індекс БШ показав стабільність співвідношення об'ємів ліквору в шлуночковій системі та субарахноїдальних просторах (табл.1). Зміна цього показника допоможе диференціювати посттравматичну гідроцефалію та дифузні атрофічні зміни [8].

Кореляція об'ємів бокових шлуночків, обчислених планіметричним методом і за допомогою гістографії, склала 0,91; головного мозку - 0,78. Нижчий показник у другому випадку пов'язано, на наш погляд, з неможливістю візуально "відняти" об'єм конвекситальних субарахноїдальних просторів при планіметричному методі.

Кореляційний зв'язок об'єму бокових шлуночків з шириною центральної частини БШ склав 0,63; з індексом центральної частини БШ - 0,61; з максимальною відстанню між передніми рогами БШ - 0,57; зі співвідношенням площини центральних частин БШ на одному зрізі до площини мозку на цьому рівні - 0,58; із площиною центральних частин БШ на одному зрізі - 0,57, з індексом передніх рогів - 0,54. 3 них найменш трудомістким є вимір ширини центральних частин. Інші показники мали значно менший зв'я3ок.

Висновки. КТ дозволяє об'єктивувати об'єм ліквору на момент дослідження і повинна застосовуватися в динамічній оцінці шлуночкової системи і субарахноїдальних просторів при ЧМТ.

Вимірювання ширини центральних частин БШ при їх симетрії в практичній діяльності лікаря-рентгенолога є достатньо об'єктивним показником стану шлуночкової системи. При необхід- 
Огляди літератури, оригінальні дослідження, погляд на проблему, короткі повідомлення, замітки з практики Таблиця 1. Середні показники розмірів шлуночкової системи в нормі залежно від віку

\begin{tabular}{|c|c|c|c|c|c|}
\hline & \multicolumn{5}{|c|}{ Вік (роки) } \\
\hline & $18-30$ & $31-45$ & $46-60$ & $61-75$ & $75-85$ \\
\hline Об'єм БШ $\left(\mathrm{cm}^{3}\right)$ & $14,1 \pm 0,23^{*}$ & $16,3 \pm 0,57$ & $19,5 \pm 1,21$ & $22,3 \pm 2,57$ & $\begin{array}{c}27,8 \pm 3,21 \\
\mathrm{p}_{2-5}<0,05\end{array}$ \\
\hline $\begin{array}{c}\text { Ширина центральних } \\
\text { частин БШ (мм) }\end{array}$ & $5,3 \pm 0,27 *$ & $7,0 \pm 0,24$ & $7,4 \pm 0,62$ & $8,6 \pm 1,17$ & $9,2 \pm 1,45$ \\
\hline $\begin{array}{c}\text { Ширина третього шлу- } \\
\text { ночка (мм) }\end{array}$ & $3,1 \pm 0,64$ & $4,3 \pm 0,71$ & $5,2 \pm 1,27$ & $\begin{array}{l}6,3 \pm 0,78 \\
p_{1-4}<0,05\end{array}$ & $6,2 \pm 1,44$ \\
\hline Об’ємний індекс БШ & $42,8 \pm 2,24$ & $46,5 \pm 2,19$ & $48,4 \pm 4,29$ & $46,8 \pm 5,17$ & $47,5 \pm 4,89$ \\
\hline
\end{tabular}

Примітка: * - різниця даних достовірна відносно всіх показників групи.

Таблиця 2. Середні показники розмірів субарахноїдальних просторів в нормі залежно від віку

\begin{tabular}{|c|c|c|c|c|c|}
\hline & \multicolumn{5}{|c|}{ Вік (роки) } \\
\hline & $18-30$ & $31-45$ & $46-60$ & $61-75$ & $75-85$ \\
\hline $\begin{array}{c}\text { Ширина передньої цистерни } \\
\text { моста (см)* }\end{array}$ & $0,5 \pm 0,09$ & $0,6 \pm 0,20$ & $0,7 \pm 0,21$ & $0,8 \pm 0,14$ & $0,8 \pm 0,12$ \\
\hline $\begin{array}{c}\text { ширина оточної цистерни } \\
\text { (см)* }\end{array}$ & $0,3 \pm 0,09$ & $0,3 \pm 1,16$ & $0,3 \pm 1,54$ & $0,4 \pm 1,27$ & $0,4 \pm 1,16$ \\
\hline $\begin{array}{c}\text { об’єм цистерни бічної ямки } \\
\left(\mathrm{cm}^{3}\right)\end{array}$ & $1,2 \pm 0,23$ & $\begin{array}{l}1,9 \pm 0,31 \\
p>0,05\end{array}$ & $\begin{array}{c}2,0 \pm 0,57 \\
p>0,05 \\
p>0,05\end{array}$ & $\begin{array}{c}3,3 \pm 0,33 \\
\mathrm{p}<0,05 \\
\mathrm{p}<0,05 \\
\mathrm{p}>0,05\end{array}$ & $\begin{array}{l}4,8 \pm 1,3 \\
p<0,05 \\
p<0,05 \\
p<0,05 \\
p>0,05\end{array}$ \\
\hline $\begin{array}{c}\text { Ширина поздовжної щілини } \\
\text { (см)* }\end{array}$ & $0,2 \pm 0,09$ & $0,3 \pm 0,14$ & $0,4 \pm 0,18$ & $0,4 \pm 0,16$ & $0,5 \pm 0,12$ \\
\hline $\begin{array}{c}\text { Ширина конвекситальних } \\
\text { борозен (см)* }\end{array}$ & $0,1 \pm 0,07$ & $0,1 \pm 0,08$ & $0,2 \pm 0,06$ & $0,2 \pm 0,08$ & $0,3 \pm 0,11$ \\
\hline $\begin{array}{c}\text { Кількість конвекситальних } \\
\text { борозен }\end{array}$ & $2,1 \pm 0,72$ & $\begin{array}{c}2,4 \pm 0,54 \\
\mathrm{p}>0,05\end{array}$ & $\begin{array}{c}3,2 \pm 1,08 \\
p>0,05 \\
p>0,05\end{array}$ & $\begin{array}{c}7,2 \pm 1,16 \\
p<0,05 \\
p<0,05 \\
p>0,05\end{array}$ & $\begin{array}{c}7,8 \pm 0,36 \\
p<0,05 \\
p<0,05 \\
p<0,05 \\
p>0,05\end{array}$ \\
\hline
\end{tabular}

Примітка: * - різниця даних у групах недостовірна $(p>0,05)$.

ності динамічного спостереження або в випадках асиметрії БШ необхідно застосовувати планіметричний метод оцінки БШ. Зміна об'ємного індексу БШ допоможе диференціювати посттравматичну гідроцефалію та дифузні атрофічні зміни головного мозку.

\section{ЛІТЕРАТУРА}

1. Зозуля Ю.А, Орлов Ю.А. Гидроцефалия: классификация, диагностика, лечение // Лікування та діагностика. - 2003. - № 4. - С. 10-15.

2. Posttraumatic ventriculomegaly: hydrocephalus or atrophy? A new approach for diagnosis using CSF dynamics / A. Marmarou, M.A. Foda, K. Bandoh et al. // J. Neurosurg. - 1996. - Vol. 85, № 6. - P. 1026-1035.

3. Верещагин Н.В., Брагина Л.К., Вавилов С.Б. и др. Компьютерная томография головного мозга.- М.: Медицина, 1986. - 256 с.

4. Корниенко В.Я., Васин Н.Я., Кузьменко В.А. Компьютерная томография в диагностике черепно-мозговой травмы. - М.: Медицина, 1987. - 288 с.
Перспективи подальших досліджень. Подальша розробка анатомо-клінічних критеріїв для оцінки лікворних просторів головного мозку та аналіз динаміки їх змін дозволить прогнозувати перебіг ЧМТ та обирати адекватні методи ії лікування.

5. Лебедев В.В., Крылов В.В. Неотложная нейрохирургия: Руководство для врачей. - М.: Медицина, 2000. - 568 с.

6. Автандилов Г.Г. Медицинская морфометрия: Руководство. - М.: Медицина, 1990. - 384 с.

7. Черний В.И., Кардаш А.М., Городник Г.А., Дроботько В.Ф. Диагностика и лечение отека и набухания головного мозга - К: Здоров'я, 1997. - 228 с.

8. Губенко О.В. Комп'ютерно-томографічна семіотика формування посттравматичних змін головного мозку при його вогнищевих контузіях: 14.01.23 Автореф. ... канд. мед. наук. - К., 2006. - 23 с. 